\title{
Dental infection simulating skin lesion *
}

\author{
Infecção dentária simulando uma lesão de pele
}

\author{
Allan Abuabara ${ }^{1}$ \\ João César Zielak ${ }^{3}$
}

\author{
Celso Alfredo Schramm ${ }^{2}$ \\ Flares Baratto-Filho ${ }^{4}$
}

\begin{abstract}
Orocutaneous fistulas or cutaneous sinus, a tract of dental origin, is an uncommon but welldocumented condition that usually requires emergency treatment. Such condition may be misdiagnosed by physicians and dentists and may sometimes be confused with bone and skin tumor, osteomyelitis, congenital fistula, salivary gland fistula, pyogenic granuloma, infected cyst, deep mycotic infection, and other pathologies. A case of facial sinus tract that was initially misdiagnosed by a physician as a nonodontogenic lesion is presented. Nonsurgical endodontic therapy was the treatment of choice for this case. Facial cutaneous sinus tracts must be considered of dental origin. Early diagnosis and prompt treatment minimize patient discomfort and esthetic problems, reducing the possibility of further complications such as sepsis and osteomyelitis.

Keywords: Cutaneous fistula; Endodontics; Fistula; Focal infection, dental; Skin diseases

Resumo: A fístula orocutânea de origem dentária é uma condição incomum, bem documentada e geralmente requer tratamento de urgência. Esta condição pode ser confundida por médicos e dentistas com lesões ósseas, de pele, nas glândulas salivares, osteomielite, granuloma piogênico, cisto infectado, infecção fúngica, entre outras. Um caso de fístula facial que foi inicialmente diagnosticado por um médico como uma lesão não-odontogênica é apresentado e discutido. O tratamento de escolha foi a endodontia do dente envolvido, sem necessidade de cirurgia. A possibilidade de infecção dentária deve ser considerada em casos de fístula cutânea na região orofacial. O diagnóstico precoce e tratamento imediato podem minimizar o desconforto do paciente e problemas estéticos, além de reduzir a possibilidade de outras complicações, como osteomielite e sepse.

Palavras-chave: Dermatopatias; Endodontia; Fistula; Fístula cutânea; Infecção focal dentária
\end{abstract}

\section{INTRODUCTION}

Dental abscesses are a common manifestation and usually require emergency treatment. In advanced stages, they may drain extraorally, depending on the causative tooth, root location, bone thickness and muscle inserts. ${ }^{1,2}$ The patient may not recall the original dental problem, especially if the infection was of a chronic and low-grade nature. ${ }^{3}$ The areas most commonly affected are the chin and submental regions. ${ }^{4}$ A case of facial sinus tract that was initially misdiagnosed by a physician as a nonodontogenic lesion is presented.

\section{CASE REPORT}

A healthy, 41-year-old female patient came spontaneously to the dental office reporting a painless, extraoral fistula originating from the left submandibular posterior region of the face. The patient reported that she had been undergoing treatment with a physician for eighteen months because of the spontaneous drainage. The initial misdiagnosis suggested by the physician was a cutaneous abscess. Unsuccessful medical treatment was performed with antibiotic therapy (cephalosporin) and drainage. The patient sought a second opinion from a dentist.

\footnotetext{
Received on 21.08.2011.

Approved by the Advisory Board and accepted for publication on 17.09.2011

* Study carried out at the University Positivo (Universidade Positivo - UP) - Curitiba (PR), Brazil

Conflict of interest: None

Financial funding: None

Specialist in Dental Radiology and Imaging - Dental surgeon, Joinville City Hall - Joinville (SC), Brazil.

MSc - Department of Dentistry, Professor of Endodontics at the University of the Joinville Region (Universidade da Região de Joinville - UNIVILLE) - Joinville (SC), Brazil PhD - Department of Dentistry, Professor of Endodontics at the University Positivo (Universidade Positivo - UP) - Curitiba (PR), Brazil.

PhD - Department of Dentistry, Professor of Endodontics at the University of the Joinville Region (Universidade da Região de Joinville - UNIVILLE) - Joinville (SC) and at the University Positivo (Universidade Positivo - UP) - Curitiba (PR), Brazil. 
Intraoral clinical examination revealed swelling in the labial sulcus adjacent to the left mandibular first and second molars. The first molar was vital. The left second molar did not respond to cold and electric pulp testing, indicating necrosis.

The cone beam computed tomography (CBCT) in panoramic view revealed occlusal restoration and bone rarefaction around the apex of the mandibular second molar consistent with a chronic apical abscess (Figure 1). The third molar was horizontal and impacted. A supernumerary molar can be seen in the mandibular ramus; the lingual bone destruction is also visible (Figure 2). After local anesthesia, nonsurgical root canal treatment was initiated and completed in a single session. Systemic antibiotic was prescribed, clindamycin hydrochloride 300mg every 8 hours for 7 days. The one-week follow-up showed a cutaneous scar without drainage (Figure 3). The surgical removal of the third molar and supernumerary molar were postponed due to the bone destruction, which could increase the risk of mandibular fracture or infection.

\section{DISCUSSION}

When a draining lesion is observed on the facial skin, an endodontic origin should always be considered in differential diagnosis. Differential diagnosis of a cutaneous draining sinus tract should include suppurative apical periodontitis, osteomyelitis, pyogenic granuloma, congenital fistula, salivary gland fistula, infected cyst and deep mycotic infection. ${ }^{1,3,5}$ Skin lesions such as pustules, furuncles, foreign-body lesions, squamous cell carcinoma, basal cell face carcinomas and granulomatous disorders may appear superficially similar to a draining sinus tract of dental origin, but they are not true sinus tracts. ${ }^{8}$ The closure of the extraoral sinus tract after elimination of the infection through nonsurgical root canal treatment, in the case herein reported, confirmed the misdiagnosis and the dental origin of the skin lesion. Clinical examination, dental radiography and sometimes CBCT can contribute to identify the location of the teeth

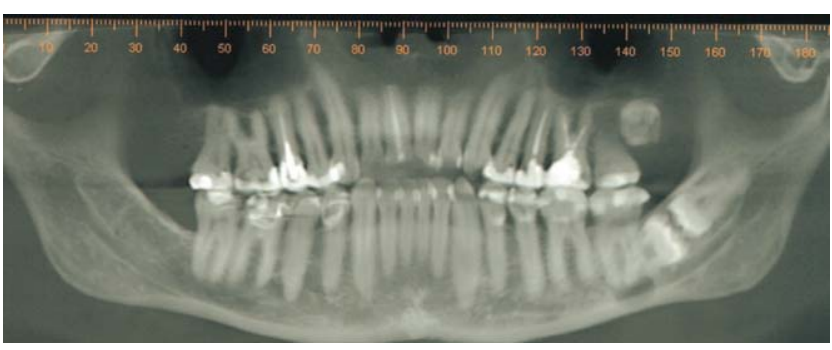

Figure 1: Panoramic view on cone beam computed tomography. A supernumerary molar can be seen in the left mandibular ramus, and bone destruction around the apex of the left mandibular second molar
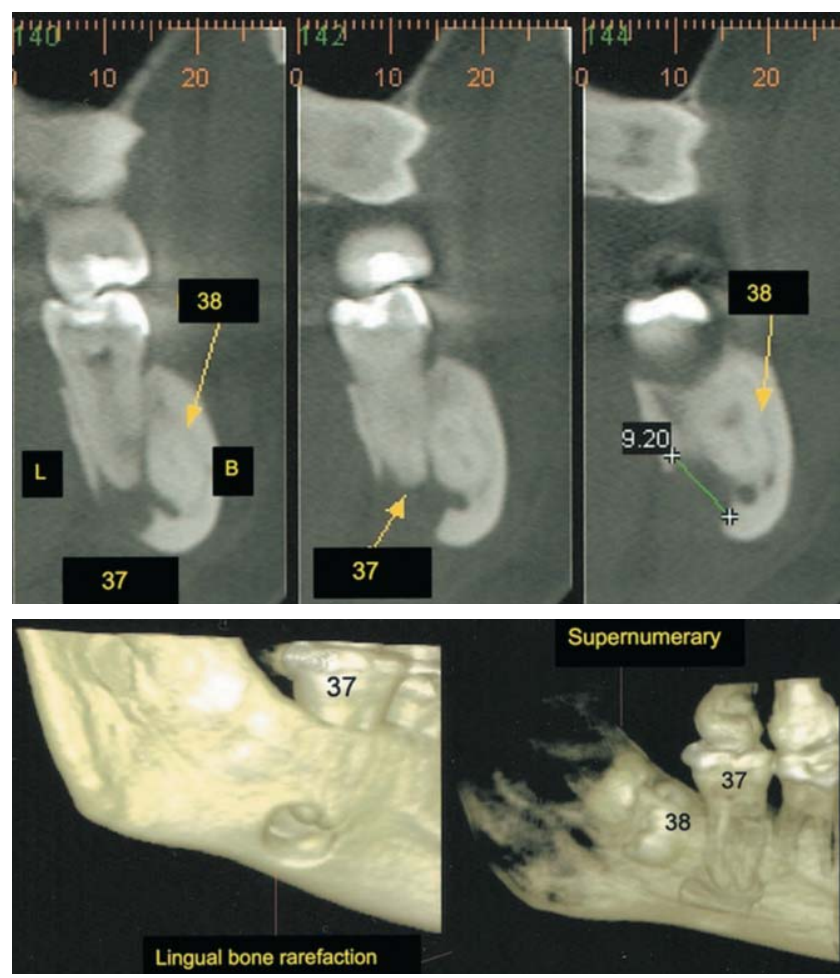

FIGURE 2: Initial cone beam computed tomography revealed the lingual bone destruction around the apex of the left mandibular second molar. $37=$ left mandibular second molar; $38=$ left mandibular third molar; $\mathrm{B}=$ buccal side; $\mathrm{L}=$ lingual side

involved, thus avoiding unnecessary antibiotic or surgical therapies.

Nonsurgical endodontic therapy, sometimes complemented by surgery or dental extraction, is the treatment of choice for extraoral sinus tracts. ${ }^{1,9}$ The tooth in this study was restorable, so endodontic therapy was performed. Definitive treatment of the draining sinus tract requires elimination of the source of infection through root canal therapy. Spontaneous closure of the tract should be expected within five to fourteen days after root canal therapy or extraction. ${ }^{7}$ In this case, the patient responded well, and the cutaneous lesions healed uneventfully. Although some difference exists in the literature regarding the removal of the sinus tract itself, most authors and more recent studies agree that once the primary odontogenic cause is removed, the sinus tract and cutaneous lesion heal without treatment. ${ }^{10}$ Healing occurs by secondary intention, in most cases. Cosmetic surgical treatment may be required at a later date if the healing results in cutaneous retraction or dimpling. ${ }^{10}$

A cutaneous sinus tract is a localized entity, which usually does not require systemic antibiotic therapy. Systemic antibiotic administration is not recommended in patients with a cutaneous odontogenic 


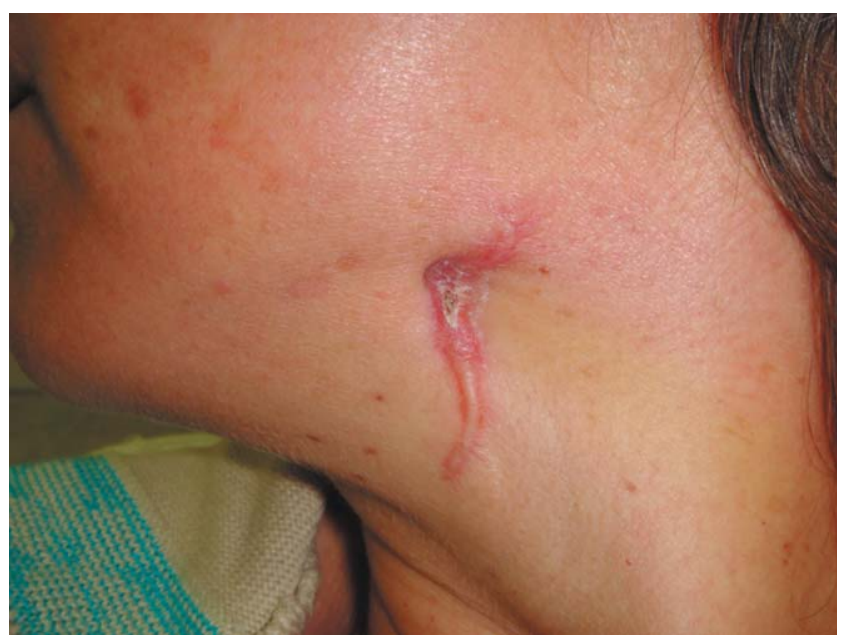

Figure 3: Lateral view of the patient. One-week follow-up showing a cutaneous scar without drainage in the left submandibular posterior region of the face sinus tract who have a competent immune system, no signs or symptoms of systemic involvement, and no systemic condition requiring prophylactic antibiotic coverage. ${ }^{10}$ In this case, due to the cutaneous draining during the endodontic filling and the endodontic file fractured in root canal, systemic antibiotic was prescribed. Clindamycin was the antibiotic of choice because it has high oral absorption, significant tissue penetration, including penetration into bone, and stimulatory effects on the host immune system. ${ }^{11}$

A case of facial sinus tract that was initially misdiagnosed as a cutaneous abscess was presented and discussed. All of the facial sinus tracts must be considered of dental origin. Early diagnosis and prompt treatment minimize patient discomfort and esthetic problems, reducing the possibility of further complications, such as sepsis and osteomyelitis.

\section{REFERENCES}

1. Pasternak-Júnior B, Teixeira CS, Silva-Sousa YT, Sousa-Neto MD. Diagnosis and treatment of odontogenic cutaneous sinus tracts of endodontic origin: three case studies. Int Endod J. 2009;42:271-6.

2. Munhoz Ede A, Bullen IR, Sant Ana E, Consolaro A. A bizarre extraoral fistula with intraoral manifestations. Braz J Otorhinolaryngol. 2007;73:849.

3. Wilson SW, Ward DJ, Burns A. Dental infections masquerading as skin lesions. $\mathrm{Br}$ J Plast Surg. 2001;54:358-60.

4. Bender IB, Seltzer S. The oral fistula: its diagnosis and treatment. Oral Surg Oral Med Oral Pathol. 1961;14:1367-76.

5. Johnson BR, Remeikis NA, Van Cura JE. Diagnosis and treatment of cutaneous facial sinus tracts of dental origin. J Am Dent Assoc. 1999;130:832-6.

6. Johnson BR, Remeikis NA, Van Cura JE. Diagnosis and treatment of cutaneous facial sinus tracts of dental origin. J Am Dent Assoc. 1999; 130: 832-6.

7. Spear KL, Sheridan PJ, Perry HO. Sinus tracts to the chin and jaw of dental origin. J Am Acad Dermatol. 1983;8:486-92.

8. Ocanha JP, Dias JT, Miot HA, Stolf HO, Marques ME, Abbade LP. Relapses and recurrences of basal cell face carcinomas.. An Bras Dermatol. 2011;86:386-8.

9. Calişkan MK, Sen BH, Ozinel MA. Treatment of extra-oral sinus tracts from traumatized teeth with apical periodontitis. Endod Dent Traumatol. 1995;11:115-20.
10. Mittal N, Gupta P. Management of extra oral sinus cases: a clinical dilemma. J Endod. 2004;30:541-7.

11. Brook I, Lewis MA, Sándor GK, Jeffcoat M, Samaranayake LP, Vera Rojas J. Clindamycin in dentistry: more than just effective prophylaxis for endocarditis? Oral Surg Oral Med Oral Pathol Oral Radiol Endod. 2005;100:550-8.

\author{
MAILING ADDRESS: \\ Allan Abuabara \\ Rua Adalberto Schmalz, 402, casa 04 condomínio \\ Ibiza - Glória \\ 89.217-260 Joinville, SC \\ E-mail: allan.abuabara@gmail.com
}

How to cite this article: Abuabara A, Schramm CA, Zielak JC, Baratto-Filho F. Dental infection simulating skin lesion. An Bras Dermatol. 2012;87(4):619-21. 